\title{
A constitucionalidade dos critérios de criação das Regiões Metropolitanas, Aglomerações Urbanas e Microrregiões previstos na Lei Federal brasileira
}

\author{
MARIANA MENCIO
}

\section{RESUMO}

O presente artigo trata da constitucionalidade de alguns dispositivos legais instituídos pela Lei Federal n. ${ }^{\circ}$ 13089/2015, denominada Estatuto da Metrópole. $\mathrm{O}$ primeiro questionamento refere-se à viabilidade da União fixar requisitos gerais para todos os Estados-membros instituírem as figuras regionais. $\mathrm{O}$ segundo diz respeito à criação de regiões metropolitanas e aglomerações urbanas que envolvem municípios pertencentes a mais de um Estado da federação. Por sua vez, a terceira questão diz respeito à distinção de tratamento estabelecida pelo legislador federal ao fixar requisitos apenas para instituição das regiões metropolitanas e aglomerações urbanas, em detrimento das microrregiões, embora estenda os efeitos da lei para este tipo de arranjo federativo.

1 Doutora em Direito Urbanístico pela Pontifícia Universidade Católica de São Paulo, São Paulo, Brasil, e professora adjunta de Direito Ambiental e Urbanístico da Universidade Federal do ABC, Santo André, Brasil. Correo-e: mariana.mencio@ufabc.edu.br Fecha de recepción: 1 de abril de 2015. Fecha de modificación: 25 de abril de 2015. Fecha de aceptación: 4 de mayo de 2015. Para citar el artículo: MENCIO, M. (2015). A constitucionalidade dos critérios de criação das Regiões Metropolitanas, Aglomerações Urbanas e Microrregiões previstos na Lei Federal brasileira. Revista Digital de Derecho Administrativo n. ${ }^{\circ}$ 13, Universidad Externado de Colombia, pp. 161-192. DOI: 10.18601/21452946.n13.09 
Plavras-chave: Estado federal, Estatuto da Metrópole, Regiões Metropolitanas, Aglomerações Urbanas.

\section{La constitucionalidad de los criterios} para la creación de las áreas metropolitanas, aglomeraciones urbanas y microrregiones en la Ley Federal Brasileña

\section{RESUMEN}

Este artículo se cuestiona acerca de la constitucionalidad de ciertas disposiciones legales establecidas en la Ley Federal n. ${ }^{\circ}$ 13089/2015, llamado Estatuto de la Metrópolis. La primera cuestión se refiere a la posibilidad de que la Unión determine requisitos generales con el fin de que todos los Estados miembros establezcan las figuras regionales. La segunda se refiere a la creación de las áreas metropolitanas y aglomeraciones urbanas que incluyen municipios pertenecientes a más de un Estado de la Federación. Por último, la tercera cuestión se refiere al tratamiento diferenciado establecido por el poder legislativo federal para establecer requisitos frente a las áreas metropolitanas y las aglomeraciones urbanas a expensas de las microrregiones, aunque se extiendan los efectos de la ley para este tipo de disposiciones federales.

Palabras clave: Estado federal, Estatuto de la Metrópolis, regiones metropolitanas, aglomeraciones urbanas, municipios.

\section{The Constitutionality of the Criteria Established for the Creation of Metropolitan Areas, Urban Conglomerations and Micro Regions in Brazilian Federal Law}

\section{ABSTRACT}

This paper deals with the question regarding the constitutionality of some articles contained in the Federal Law n. ${ }^{\circ}$ 13089/2015 (Statute of the metropolis). The first question is about the viability of the Federation (União) in setting up general requirements for all federate states to institute the administrative regional figures. The second question is about how to establish metropolitan 
regions and urban conglomerations that include municipalities belonging to more than one state. The third question is the different treatment established by the federal law: There are requirements for metropolitan regions and urban conglomerations, but there are no requirements for micro regions. However, by analogy, the federal law also applies to this type of federal arrangement.

Keywords: Federal State, Status of Metropolis, Metropolitan Regions, Urban Conglomerations, Municipalities.

\section{INTRODUÇÃO}

Em 12 de janeiro de 2015, foi instituído o Estatuto da Metrópole com o propósito de fixar as diretrizes gerais para o planejamento, a gestão e a execução das funções públicas de interesse comum em regiões metropolitanas e aglomerações urbanas instituídas pelos Estados. Além disto, o diploma federal estabeleceu normas gerais sobre o plano de desenvolvimento urbano integrado e outros instrumentos de governança interfederativa, bem como critérios para o apoio da União a ações que envolvam governança interfederativa no campo do desenvolvimento urbano. Contudo, optamos por refletir apenas sobre três aspectos introduzidos por esta lei federal, referente à criação das regiões metropolitanas, aglomerações urbanas e microrregiões pelo Estado-Membro da federação, por força do artigo 25, §3 da Constituição Federal de $1988^{2}$.

De acordo com o dispositivo mencionado, compete aos Estados-Membros da federação brasileira a instituição das figuras regionais, nos termos da lei complementar por ele editadas. Entretanto, o Estatuto da Metrópole nos dispositivos legais previstos nos artigos $1 .^{\circ}, \S 1 .^{\circ}, \mathrm{I}, 2 .^{\circ}, \mathrm{I}, \mathrm{V}, \mathrm{VII}, 3 . .^{\circ}, 4 .^{\circ}, 5^{\circ} \mathrm{e}$ 15 estabeleceu conceitos de metrópole, aglomeração urbana e região metropolitana. Com relação às microrregiões, ainda que não tenha definido seus contornos legais, incluiu a figura no âmbito de aplicação da lei. Além disto, o diploma legal estabeleceu os conteúdos mínimos da lei complementar estadual responsável pela criação das figuras regionais e permitiu a criação de regiões metropolitanas que envolvam municípios pertencentes a mais de um Estado.

Diante das inovações legislativas introduzidas pela lei federal n. ${ }^{\circ}$ 13089/2015, é fundamental analisarmos a constitucionalidade dos dispositivos legais, à luz da divisão constitucional de competências federativas brasileiras, com o intuito de avaliarmos as várias possibilidades de interpretação dos dispositivos legais, buscando sustentar a permanência apenas das normas que revelam

2 Artigo 25, § $3 .^{\circ}:$ : Os Estados poderão, mediante lei complementar, instituir regiões metropolitanas, aglomerações urbanas e microrregiões, constituídas por agrupamentos de municípios limítrofes, para integrar a organização, o planejamento e a execução de funções públicas de interesse comum integrar a organização, o planejamento e a execução de funções públicas de interesse comum". 
conteúdo material e formal compatível com o texto constitucional. Trata-se da possibilidade de promovermos a interpretação conforme a Constituição, com o intuito de viabilizar a permanência dos dispositivos legais, desde que seus sentidos sejam adequados ao texto constitucional.

Deste modo, abordaremos algumas questões referentes ao tratamento do ordenamento jurídico brasileiro atribuído às figuras regionais, bem como os requisitos previstos pela Constituição federal de 1988 para sua criação, com o propósito de formularmos interpretações dos dispositivos do Estatuto da Metrópole adequados ao sentido das normas constitucionais.

\section{NATUREZA JURÍDICA DAS REGIÕES METROPOLITANAS, AGLOMERAÇÕES URBANAS E MICRORREGIÕES NO SISTEMA JURÍDICO BRASILEIRO ${ }^{3}$}

Com base na conceituação do professor Pedro Estevam SerRano (2009, p. 190) sobre regiões metropolitanas é possível compreender a sua natureza jurídica e ampliar este regime para as aglomerações urbanas e microrregiões, nos termos da CF/1988. Apesar dos Estados-Membros titularizarem a competência exclusiva para institucionalizar as figuras regionais urbanas, a carta constitucional não tratou as regiões metropolitanas, aglomerações urbanas e microrregiões como entes federados, uma vez que não menciona nos dispositivos constitucionais sua natureza federativa. Prevê o artigo $1 .^{\circ}$ que a República Federativa do Brasil constitui-se em Estado Democrático de Direito, formada pela união indissolúvel dos Estados, Municípios e Distrito Federal. Por sua vez, o artigo 18 prescreve que a organização político-administrativa da República Federativa do Brasil compreende a União, os Estados, o Distrito Federal e os Municípios, sem referência às unidades regionais. Neste sentido, o professor Pedro EsteVAm (2009, p. 190) conceitua regiões metropolitanas da seguinte forma: "Ente administrativo estadual, da administração direta ou indireta, sob regime de Direito Público, instituída por competência discricionária do legislador complementar estadual por conta do permissivo constitucional do $\$ 3 .^{\circ}$ do artigo 25 de nossa Carta Magna, em áreas de conurbação de três ou mais Municípios em que haja a necessidade de realização de atividades comuns de caráter regional, no interior dos limites da competência constitucional do Estado-membro e em seu nome e sob sua responsabilidade, realizados por ges-

3 Apontamentos extraídos do artigo de nossa autoria denominado "Considerações acerca da constitucionalidade dos dispositivos legais que priorizam o acesso aos incentivos financeiros da União para os Estados e Municípios integrantes de microrregiões na elaboração dos planos estaduais e municipais de resíduos sólidos", publicado no Boletim de Direito Municipal, outubro de 2012, NDJ, p. 712-738. 
tão compartilhada com os Municípios integrantes, nos limites e organização estipulados na lei instituidora, sem interferência na autonomia municipal".

As figuras regionais urbanas não são entes federados. Neste sentido, verificamos que por força dos artigos $1 .^{\circ}, 18$, caput, 25, 29, 30, 34, VII, c da CF, apenas a União, os Estados, o Distrito Federal e os Municípios são considerados entes federados, dotados de autonomia, no sentido de apresentarem a tríplice capacidade de auto-organização e normatização própria, autogoverno e auto administração. É por isto que a Constituição Federal, ao disciplinar a autonomia de cada um dos entes federados, atribui competências legislativas e administrativas, sendo que o conjunto de competências legislativas caracteriza a autonomia política, ou seja, a elaboração de normas jurídicas.

Com relação às figuras regionais o constituinte não atribuiu este regime jurídico de ente federado. Na realidade, de acordo com os ensinamentos dos professores Hely Lopes Meirelles (Direito Municipal Brasileiro, 2001), REGIna Maria Macedo Néri Ferrari (Direito Municipal, 2005) e Pedro Estevam SERRANO (2009, p. 190), as regiões metropolitanas, aglomerações urbanas e microrregiões decorrem da realidade fática de conurbação urbana, que por força de lei estadual poderão ser criadas ora como órgão da administração direta (Secretaria do Estado) ora como pessoa jurídica da administração indireta (autarquia, empresa pública e sociedade de economia mista) para fins de organização, planejamento e execução das funções públicas de interesse comum. Esta é a opinião sustentada.

Assim, as figuras regionais não podem avocar para si competências de quem efetivamente é ente federado, como no caso dos Municípios. Deste modo, realizando uma interpretação conforme com o regime constitucional federativo, o conteúdo do artigo $25, \S 3 .^{\circ}$ da Constituição Federal, deve ser interpretado, nas lições de PEDro EsteVAM SERRANO (2009, p. 190) da seguinte forma: "Prerrogativa de decidir quanto ao modo de exercer a competência que lhe foi outorgada pelo sistema federativo, autorizando fazê-lo de forma centralizada e solitária ou realizando-a de forma descentralizada, contando com a participação dos Municípios. Por ser uma entidade apenas administrativa, sem personalidade política, a Região Metropolitana em nada deve interditar a competência do Município enquanto ente federado. Esta Região significa apenas um campo de atuação de competência estadual determinada pela Constituição Federal, não se configurando com novo ente político capaz de titularizar competências diferenciadas e, com muito menos razão, com a prerrogativa de suprimir competências constitucionalmente estabelecidas". Compartilham o mesmo entendimento acima esposado os professores ALAÔR Caffé Alves (Regiões Metropolitanas, 1998), Ana Carolina Wanderley TeIXEIRA (Região Metropolitana, 2009) e MANOEL GONÇALVES FERREIRA FILHO (A democracia possível, 1999, p. 58). 


\section{NOÇÕES GERAIS SOBRE REGIÕES METROPOLITANAS, AGLOMERAÇÕES URBANAS E MICRORREGIÕES NO SISTEMA JURÍDICO BRASILEIRO ${ }^{4}$}

Iniciaremos a nossa reflexão com algumas digressões sobre o termo metrópole, antes de o relacionarmos com regiões.

Entre os vários sentidos a ele atribuídos, do ponto de vista dos urbanistas e cientistas sociais a expressão diz respeito às grandes áreas urbanas e interurbanas espalhadas territorialmente (SPINK, TEIXEIRA e ClEMENTE, 2009, p. 456). Isto significa dizer que, por meio do incremento da urbanização pelo processo de industrialização e intenso crescimento demográfico, as extensões urbanas foram se alastrando e ampliando os limites físicos da cidade, o que levou vários geógrafos, estatísticos e economistas a compreenderem o fenômeno por meio de conceitos como metrópole, megapolo, megalópole, aglomeração, área urbana e metápole (LEFÉVRE, 2009, p. 304). Do ponto de vista semântico, o termo Metrópole tem origem grega e significa cidade mãe, (metra-úteropólis), principal centro urbano, adotada inclusive pelos romanos como uma referência à capital da província (SPINK, TEIXEIRA y ClEMENTE, 2009, p. 456). O vocábulo faz menção à noção de centralidade política e hegemônica (SPINK, Teixeira y Clemente, 2009, p. 457).

Por outro lado, vale a pena também examinarmos a definição trazida pelo dicionário (FERREIRA, 1994) sobre Região e Região Metropolitana. Destacaremos dentre os seus vários sentidos aquele referente ao tema de nossa investigação. Região na terminologia latina é substantivo feminino e corresponde à grande extensão de terreno. Por sua vez, Região Metropolitana é região densamente urbanizada constituída por municípios que, independentemente de sua vinculação administrativa, fazem parte da mesma comunidade socioeconômica, e cuja interdependência gera a necessidade de coordenação e realização de serviços de interesse comum.

Assim, ao tratamos das noções gerais sobre o conceito de Região Metropolitana, verificamos que o fenômeno pode ser estudado sob os aspectos fático-urbanístico (realidade urbana e econômica) e jurídico. O fenômeno fático-urbanístico se transforma em instituto jurídico quando é instituído por lei complementar estadual (artigo 25, §3..$^{\circ}$ da Constituição Federal). Neste caso, cuidaremos das abordagens urbanísticas e econômicas, que servirão para descrever os elementos da hipótese normativa, isto é, a situação fática juridicamente qualificada.

4 V. tese de doutorado denominada "Regime Jurídico dos Planos Diretores Metropolitanos", defendida no dia 18/2/2014 perante banca examinadora na Pontifícia Universidade Católica, p. 183-233. Disponível para consulta: http://www.sapientia.pucsp.br//tde_busca/ arquivo.php?codArquivo $=16696$ 
Não existe conceito universal aplicável às figuras regionais, pois caberá ao ordenamento jurídico de cada país definir os contornos jurídicos das regiões metropolitanas, conforme esclarece JuAN CARLOS CoviLla MARTINEZ (2010, p. 157): "No existe um concepto global de la palabra metrópolis, por lo que corresponde a cada ordenamiento fijar su definición de acuerdo com las características de cada país, buscando ante todo un desarrollo metropolitano".

A formação das regiões metropolitanas tem relação com o intenso crescimento urbano decorrente do surgimento das cidades. Para JOSÉ AfONSO DA Silva (2012, p. 24), é possível estabelecer juridicamente um conceito de cidade: "Cidade, no Brasil, é um núcleo urbano qualificado por um conjunto de sistemas político-administrativo, econômico não - agrícola, familiar e simbólico como sede do governo municipal, qualquer que seja sua população. A característica marcante da cidade no Brasil consiste no fato de ser um núcleo urbano, sede do governo municipal".

De outro lado, o Município é ente federado, tem autonomia política, é capaz de editar suas próprias leis, criar sua própria estrutura administrativa através da Lei Orgânica e executar suas funções, nos termos da Constituição Federal.

No Brasil, as cidades experimentaram a partir da década de 60, um intenso processo de industrialização, acompanhado do aumento de riqueza econômica, crescimento demográfico, implementação de equipamentos urbanos (ruas, praças, canalizações subterrâneas, viadutos, escolas, mercados), estrutura edilícia para abrigar o elevado contingente populacional, o que acarretou o desenvolvimento de relações sociais, comerciais, culturais e industriais. Contudo, o acelerado crescimento das cidades, decorrente da intensificação dos fluxos econômicos, sociais e culturais gerou a expansão dos núcleos urbanos, circunscritos a uma única sede de Município para outras cidades vizinhas, criando vínculos entre cidades de municípios próximos, gerando relações de graus distintos de interdependência.

A região metropolitana é fruto do crescimento da cidade para além dos limites territoriais do município no qual está inserida. Neste processo há sempre um núcleo urbano principal que exerce influência econômica e social em relação aos núcleos urbanos das cidades vizinhas, contidas em outros Municípios. A interdependência entre os núcleos urbanos em grau elevado forma um único aglomerado com relações mútuas, denominado conurbação. Na verdade, conturbação (FERREIRA, 1994, p. 470) é o conjunto formado por uma cidade e seus subúrbios, ou por cidades reunidas, que constituem uma sequência, sem, contudo, se confundirem.

Dependendo das características econômicas, sociais e urbanas que geram a interdependência entre as cidades de vários municípios, distintos tipos de regiões metropolitanas poderão surgir. Por exemplo, o Estado de São Paulo, atualmente, conta com 5 regiões: São Paulo, Campinas, Santos, Vale do Paraíba e Litoral Norte e a Região Metropolitana de Sorocaba. A Região Metropolitana de São Paulo, por exemplo, foi criada pela Lei Complementar n. ${ }^{\circ} 1.139$ 
de 16 de junho de 2011, e tem $8097 \mathrm{Km}^{2}$, 39 municípios, 5 sub-regiões, 19, 7 milhões de habitantes e 572 bilhões de reais de PIB (Reorganização da Região Metropolitana de São Paulo consolida novo sistema de gestão, 2008). Por sua vez, a Região Metropolitana do Vale do Paraíba e Litoral Norte, criada pela Lei Complementar n. ${ }^{\circ} 1.166$ de 9 de janeiro de 2012, conta com $16.178 \mathrm{Km}^{2}$, 39 municípios, 5 sub-regiões, 2.264 .594 habitantes, 55, 6 bilhões de reais de PIB e 94 \% taxa de urbanização (Região Metropolitana do Vale do Paraíba e Litoral Norte, 2011).

Sob o aspecto jurídico compreendemos que o fenômeno urbano descrito é transformado em realidade jurídica quando instituído pelo artigo $25, \S 3 .^{\circ}$, da Carta Constitucional por Lei Complementar Estadual. No entanto, esta criação parte de substratos da realidade econômica, social e urbanística, conforme observamos nas palavras de JOSÉ AfONSO DA SILVA (2012, p. 24): "O desenvolvimento industrial gerou a grande cidade dos nossos dias, cujo crescimento acelerado amplia a urbanização de áreas próximas, interligando núcleos vizinhos, subordinados às Administrações autônomas diversas. Essa continuidade urbana, que abrange vários núcleos subordinados a Municípios diferentes, gera problemas específicos que demandam solução uniforme e comum. Mesmo sem essa continuidade urbana surgem situações urbanas contíguas, polarizadas ou não por um núcleo principal, que requerem organização jurídica especial que propicie tratamento urbanístico adequado ao aperfeiçoamento da qualidade de vida de todo o assentamento humano da área. Esse fenômeno, que resulta da expansão urbana, constitui uma realidade fática, sociológica, e se transforma, entre nós, em entidades jurídicas, como regiões metropolitanas, aglomerações urbanas ou microrregiões, quando instituídas por lei complementar estadual, na forma prevista pelo artigo $25, \S 3^{\circ}$, da $\mathrm{CF}^{\prime \prime}$.

Como parâmetro legislativo, invocaremos as definições de regiões metropolitanas das legislações paulistas e mineiras, em razão do elevado grau de aperfeiçoamento da gestão metropolitana implementado nestes dois estados da federação. Com base no artigo 153 da Constituição Estadual de São Paulo e do artigo $3 .^{\circ}$ da Lei Complementar n. ${ }^{\circ} 760 / 1994$ que instituiu as diretrizes para organização regional do Estado de São Paulo, região metropolitana é definida como sendo agrupamento de municípios limítrofes que assuma destacada expressão nacional, em razão de elevada densidade demográfica, significativa conurbação e de funções urbanas e regionais com alto grau de diversidade, especialização e integração sócio-econômica, exigindo planejamento integrado e ação conjunta permanente dos entes públicos nela atuantes. De acordo com os artigos 44 e 45 da Constituição Estadual de Minas Gerais e do artigo $3 .^{\circ}$ da Lei Complementar n. ${ }^{\circ} 88$ de 12/1/2006, as regiões metropolitanas são formadas por municípios limítrofes que apresentam a ocorrência ou a tendência de continuidade do tecido urbano e de complementaridade de funções urbanas, que tenha como núcleo a capital do Estado ou metrópole regional e que exija planejamento integrado e gestão conjunta permanente por parte dos 
entes públicos nela atuantes. Neste caso, a lei exige para criação das regiões metropolitanas a comprovação da existência de requisitos legais que demonstrem na prática a existência da figura regional, por meio de parecer técnico. Assim, o parecer técnico deverá levar em conta no ato da criação da região a existência dos seguintes fatores: I - população e crescimento demográfico, com projeção qüinqüenal ${ }_{i}$ II - grau de conurbação e movimentos pendulares da população; III - atividade econômica e perspectivas de desenvolvimento; IV - fatores de polarização; $\mathrm{V}$ - deficiência dos serviços públicos, em um ou mais Municípios, com implicação no desenvolvimento da região. Por outro

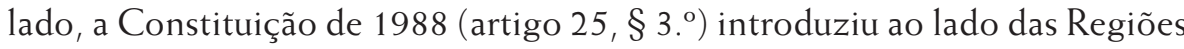
Metropolitanas as figuras regionais, Aglomerações Urbanas e Microrregiões, ambas formadas por Lei Complementar Estadual para integrar a organização, o planejamento e a execução de funções públicas de interesse comum. Diante desta previsão constitucional, podemos formular a seguinte questão: o sentido das figuras regionais, introduzidas pela Constituição Federal de 1988, coincide com o conceito de Região Metropolitana?

O principal desafio é identificarmos as distinções e semelhanças entre as figuras regionais. Segundo JosÉ AfONSO DA SILVA (2012, p. 156), "Regiões Metropolitanas constitui-se de um conjunto de Municípios cujas sedes se unem com certa continuidade urbana em torno de um Município ${ }_{i}$ Microrregiões forma-se de grupos de Municípios limítrofes com certa homogeneidade e problemas administrativos comuns, cujas sedes não sejam unidas por continuidade urbana. Aglomerações Urbanas carecem de conceituação, mas de logo se percebe que se trata de áreas urbanas sem um pólo de atração urbana, quer tais áreas sejam das cidades-sedes dos Municípios, como na Baixada Santista, ou não".

Quanto à distinção conceitual entre as figuras regionais, RAFAEL AUGUSTO SiLVA DOMINGUES (2010, p. 172), compartilha o entendimento de JOSÉ AFONSO DA SILVA. As microrregiões não apresentam continuidade urbana. Por sua vez, as aglomerações urbanas, embora muito semelhantes às regiões metropolitanas, não contam com um Município-polo que exerça atração em relação aos Municípios limítrofes.

Do ponto de vista legal, identificamos a definição destas figuras nas Constituições Estaduais, que nem sempre revelam o mesmo sentido atribuído pela doutrina. Como exemplo, citaremos as legislações dos Estados de São Paulo e Minas Gerais embora vários outros tenham instituído Regiões Metropolitanas e outras figuras regionais.

O artigo 153, § 2. ${ }^{\circ}$ da Constituição do Estado de São Paulo e o artigo $4 .^{\circ}$ da Lei Complementar n. ${ }^{\circ}$ 760/1994 consideram aglomeração urbana o agrupamento de Municípios limítrofes que apresente relação de integração funcional de natureza econômico-social e urbanização contínua entre dois ou mais Municípios ou manifesta tendência nesse sentido, que exija planejamento integrado e recomende ação coordenada dos entes públicos nela atuantes. Por sua vez, o artigo 153, § 3. ${ }^{\circ}$ da Constituição do Estado de São Paulo e o artigo 
5. ${ }^{\circ}$ da Lei Complementar 760/1994 qualificam a microrregião como o agrupamento de Municípios limítrofes que apresente, entre si, relações de interação funcional de natureza físico-territorial, econômico-social e administrativa, exigindo planejamento integrado com vistas a criar condições adequadas para o desenvolvimento e integração regional.

O Estado de Minas Gerais, quanto às definições de Aglomerações Urbanas e Microrregiões, só conta com previsão na sua Constituição (artigos 48 e 49). O artigo 48 considera aglomeração urbana o agrupamento de Municípios limítrofes que apresentam tendência à complementaridade das funções urbanas que exija planejamento integrado e recomende ação coordenada dos entes públicos.

Por outro lado, o artigo 49 considera microrregião o agrupamento de Municípios limítrofes resultante de elementos comuns físico-territoriais e socioeconômicos que exija planejamento integrado com vistas a criar condições adequadas para o desenvolvimento e a integração regional.

Diante da variedade de conceitos legislativos e doutrinários, MARIA COELI Simões Pires e Gustavo Gomes MaCHado (2008, p. 417), explicam as dificuldades para identificar essas noções na prática: “A expressão aglomeração urbana raramente aparece na legislação, e o conceito é pouco desenvolvido na doutrina mais consolidada sobre planejamento e gestão urbana. A primeira referência urbana a tal unidade regional consta na Lei Federal n. ${ }^{\circ}$ 6.766/1979, no artigo 13 , sendo, porém omissa a norma quanto à conceituação da espécie. Em linhas gerais, uma aglomeração urbana apresenta algumas das características que qualificam a região metropolitana, nisso reside a dificuldade de defini-la. É ela igualmente um complexo geoeconômico formado por municípios limítrofes e caracterizado por certo grau de conurbação e pela presença de problemas urbanos de repercussão regional, para cuja solução são necessárias ações compartilhadas entre os entes federativos envolvidos. A constitucionalização da espécie, à sua vez, desafia o novo Direito Urbanístico a precisar-lhe o conceito e a apontar, compreender e explicar os seus desdobramentos teóricos e pragmáticos. Na verdade, a doutrina tem buscado a diferenciação conceitual entre região metropolitana e aglomeração urbana, a partir da metodologia utilizada para a hierarquização da chamada Rede Urbana Brasileira, importante subsídio à formulação de políticas públicas de planejamento territorial de âmbito nacional, regional e municipal, como se colhe da lição de MOTTA e AJARA (2000). A rede urbana do país, [...], compreende o conjunto de centros urbanos que polarizam o território nacional e os fluxos de pessoas, bens e serviços que se estabelecem entre eles e com as respectivas áreas rurais. É formada por centros urbanos de dimensões variadas, que estabelecem relações dinâmicas entre si de diferentes magnitudes. São estas interações que respondem, não apenas pela atual conformação espacial da rede, mas também por sua evolução futura, cuja compreensão é fundamental para o estabelecimento de metas de políticas públicas" (MACHADO e PIRES, 2008, p. 417). 
$\mathrm{Na}$ realidade, aglomeração urbana e as outras figuras regionais são fatos jurídicos, que partem de fenômenos da realidade para receberem consequências jurídicas. Portanto, não há que se falar em equívoco por parte do constituinte brasileiro. Assim, se o dispositivo constitucional remeteu às leis complementares estaduais a definição da figura regional, a caracterização do fenômeno partirá de conceitos urbanos, econômicos, para ser qualificado como realidade jurídica por meio de lei complementar.

Diante do suporte técnico, baseado na metodologia utilizada para a hierarquização da chamada Rede Urbana Brasileira, MARIA CoELI SimÕES PIRES e GUSTAVO GOMES MACHADO (2008, p. 418) conceituam aglomerações urbanas como um conjunto de municípios intensamente urbanizados ou até mesmo conurbados, com posição intermediária na hierarquia da rede urbana, cuja interação exige compartilhamento de funções em razão da insuficiência de ações isoladas por parte dos municípios.

Por sua vez, ao contrário da conurbação das aglomerações e regiões metropolitanas, as funções públicas de interesse comum das microrregiões estão relacionadas à interação funcional de natureza físico-territorial, econômicosocial e administrativa entre os municípios, que exigem planejamento integrado, com vistas à criação de condições adequadas para desenvolver potencialidades e superar limitações para o desenvolvimento.

Deste modo, podemos perceber que a realidade que caracteriza cada uma das figuras regionais leva em conta distintos tipos de relações entre os municípios limítrofes, o grau de influência que determinada cidade exerce em relação à outra, consubstanciada na ideia de hierarquia entre os núcleos urbanos.

Do ponto de vista técnico, o critério de hierarquia, isto é, nível de importância socioeconômica das cidades que integram uma das três regiões, leva em consideração os seguintes fatores: densidade demográfica, grau de deslocamento da população entre as cidades integrantes das regiões, por motivos de estudo e trabalho e a capacidade de produção e comércio de bens e serviços. Assim, se o grau de importância apresentado por uma cidade em relação às demais em função dos fatores apresentados, uma delas exercerá grau máximo de atração socioeconômica em relação à outra, desempenhando o papel de metrópole em relação aos outros centros. De outro extremo, se o grau de importância da cidade em relação às outras cidades não for elevada, ela será considerada um centro local, sem exercer sobre outra qualquer influência a ponto de extrapolar os limites territoriais.

As relações surgirão dependendo do desenvolvimento da região. A capacidade de atração máxima entre as cidades, em termos socioeconômicos, poderá ser baseada tanto em uma cidade que apresente toda a infraestrutura urbana, de prestação de serviços e indústrias, como modelo monocêntrico (que atrai permanentemente a população do entorno para satisfação de suas necessidades) quanto em cidades de modelo policêntrico (quando várias delas apresentam 
infraestrutura e ampla rede de serviços, que aos poucos rompem com o grau de polarização e dependência em relação aos demais centros urbanos).

Portanto, a hierarquia de rede urbana está relacionada à capacidade de atração e liderança exercida por determinada cidade em relação às outras, em função de oferta de serviços, equipamentos urbanos e densidade demográfica, o que gera distintos graus de conurbação entre os núcleos urbanos.

Do ponto de vista urbano, identificamos entre as figuras regionais graus de importância e interdependência entre as cidades e municípios envolvidos. Observamos, por exemplo, que tanto na Região Metropolitana quanto na Aglomeração Urbana o fenômeno da conurbação está presente, isto é, o crescimento de várias cidades que extrapolam o núcleo urbano de um município passando a integrar outros municípios, através de relações com as cidades vizinhas. O grau elevado de urbanização faz desaparecer as zonas rurais entre as cidades interligadas e o predomínio da grande zona urbana, formada pela junção dos municípios limítrofes. Isto significa que, nas duas regiões, as áreas urbanizadas estão interligadas a mais de um Município, a partir da articulação entre vários núcleos urbanos em relação aos diversos municípios. Por sua vez, as microrregiões não contam com o fenômeno da conurbação. Cada núcleo urbano, com sua zona urbana e rural, pertence a um Município. Os municípios apresentam entre si relações físico-territoriais, econômico-sociais, administrativas, mas sem extrapolar suas respectivas fronteiras. A microrregião conta com características de homogeneidade físico-territorial (os municípios poderão pertencer às mesmas unidades de conservação ou Unidades de Gerenciamento de Recursos Hídricos - UGRGI) e socioeconômica. Destacamos, por exemplo, a criação da Microrregião de São Roque (Rede Urbana e Regionalização do Estado de São Paulo, 2011). Ela abrangerá cinco municípios, no eixo Raposo TAVARES-CASTELO BRANCO, que apresentam ligações funcionais com Sorocaba. Todos pertencem à mesma UGRGHI e com relação à ocupação do solo, predominam chácaras de recreio. A economia é diversificada. Convivem municípios industriais com outros pautados na prestação de serviços. Os Municípios estão inseridos na UGRGI Tietê-Sorocaba, que apresenta balanço hídrico crítico, e não abrigam unidades de conservação (Rede Urbana e Regionalização do Estado de São Paulo, 2011).

Deste modo, o critério técnico que informará a definição jurídica das várias tipologias regionais levará em conta o grau de complexidade e tangenciamento da malha urbana entre as cidades de Municípios. Assim, a conurbação entre os Municípios sempre existirá nas Regiões Metropolitanas em grau de complexidade elevado. Mas está em estágio de formação nas aglomerações urbanas e não existe nas microrregiões, uma vez que as cidades integrantes permanecerão nos limites de seus Municípios que contarão com áreas rurais e urbanas, sem apresentar entre si o tangenciamento entre seus territórios.

O Estado de São Paulo criou pela Lei Complementar n. ${ }^{\circ} 1.146$ de 24/8/2011 a Aglomeração Urbana de Jundiaí. Ainda não foram criadas microrregiões, 
embora tenha sido proposto o Projeto de Lei Estadual n. ${ }^{\circ}$ 32, publicado em 11/5/2011 que cria a microrregião de São Carlos formada pelos Municípios de Analândia, Descalvado, Dourado, Ibaté, Ribeirão Bonito e São Carlos ${ }^{5}$.

Todavia, o fato jurídico regional - denominado assim, por referir-se às três entidades do artigo $25, \S 3 .^{\circ}$ da Constituição Federal - não conta com a noção de hierarquia entre região metropolitana, aglomeração urbana ou microrregião.

Do ponto de vista jurídico, hierarquia significa ordem, subordinação de poderes ou série contínua de graus ou escalões, em ordem crescente ou decrescente (FERREIRA, 1994). Em termos de regiões previstas pela Constituição Federal, não há vínculo de subordinação em relação à outra tipologia. Quando se fala em hierarquia das redes consideramos aspectos da realidade fática, geográficos, urbanísticos que demonstram grau de desenvolvimento elevado de um centro urbano em relação a outro capaz de atrair o crescimento e a expansão dos centros limítrofes.

Sobre o tratamento jurídico dado às aglomerações urbanas e microrregiões, sustentamos que o mesmo regime jurídico atribuído às Regiões Metropolitanas deve ser aplicado, sobretudo, com relação ao vínculo compulsório presente nos Municípios integrantes das três figuras regionais.

$\mathrm{Na}$ verdade, a distinção entre região metropolitana, aglomeração urbana e microrregião reside apenas na realidade urbana, fática, disposta na hipótese da norma jurídica. Verificamos por meio da legislação do Estado de São Paulo e de Minas Gerais ${ }^{7}$ que estes elementos deverão constar em estudos técnicos ou pareceres para justificar a edição das leis complementares que vão criar as figuras regionais.

Quanto ao fato jurídico regional, as três realidades apresentam regimes jurídicos semelhantes.

\section{REQUISITOS DE CRIAÇÃO DAS FIGURAS REGIONAIS PREVISTAS NO ARTIGO 25, § 3. ${ }^{\circ}$ DA CONSTITUIÇÃO FEDERAL DE 1988}

Nosso objetivo neste momento é identificar os requisitos exigidos pela Constituição e Leis estaduais para sabermos se o legislador estadual tem liberdade,

5 Projeto de Lei n. ${ }^{\circ}$ 32/2011, Microrregião de São Carlos, artigo 3. ${ }^{\circ}$, Fica criado o Conselho de Desenvolvimento da Microrregião de São Carlos, de caráter deliberativo e normativo, composto por representante do município integrante da região e por representantes do Governo do Estado de São Paulo, nos campos funcionais de interesse comum e garantida a paridade das decisões nos termos dos artigos 9. ${ }^{\circ}$ e 16 da Lei Complementar n. ${ }^{\circ} 760$, de 1. ${ }^{\circ}$ de agosto de 1994, e artigo 154 da Constituição do Estado de São Paulo.

6 Lei Complementar n. ${ }^{\circ} 760 / 1994$, artigo 6. ${ }^{\circ}$

7 Constituição do Estado de Minas Gerais, artigo 44. 
ou melhor, discricionariedade ampla para criar as figuras regionais ou se está submetido aos estritos limites da lei, no âmbito do exercício de competência vinculada.

O Poder Constituinte originário conferiu ao poder constituinte dos Estados uma faculdade (artigo $25, \$ 3 .^{\circ}$ da Constituição) ao redigir no texto constitucional a expressão "poderão", atrelada a parâmetros para o exercício da competência legislativa, quais sejam: a) Instituição das figuras regionais por lei complementar estadual; b) existência de agrupamentos de municípios limítrofes; c) finalidade de integrar a organização, planejamento e execução de funções públicas de interesse comum (SERRANO, 2009, p. 186).

Da mesma forma, a Constituição Federal permite que o Poder Constituinte derivado decorrente, por meio de suas próprias constituições (ANNA CÂNDIDA DA CUNHA FERRAZ, 1979, p. 19) ${ }^{8}$, estabeleça requisitos diferenciados para formar as figuras regionais, além dos previstos no artigo $25, \S 3$. $^{\circ}$ Trata-se da observância do princípio da simetria, de acordo com a terminologia da jurisprudência. O Poder Constituinte dos Estados-membros está vinculado à observância dos princípios magnos e estruturantes do Estado, previstos na Constituição. O quanto possível, deverão ser reproduzidos de forma simétrica nos textos das Constituições Estaduais.

Assim, se não respeitarem os parâmetros do Poder Constituinte Originário, as disposições das cartas estaduais serão inconstitucionais. Com base nos dis positivos das Constituições Estaduais, analisaremos a legislação dos Estados de São Paulo e Minas Gerais sobre o assunto.

Por força do artigo $6 .^{\circ}$ da Lei Complementar n. ${ }^{\circ} 760 / 1994^{9}$ do Estado de São Paulo, os projetos de lei complementar que tratem da criação das unidades regionais ou a modificação de seus limites territoriais ou de sua designação deverão ser instruídos com o parecer da Secretaria de Planejamento e Gestão demonstrando as características definidas, por exemplo, para Região Metropolitana ${ }^{10}$ : elevada densidade demográfica, significativa conurbação, funções urbanas e regionais com alto grau de diversidade e especialização e integração socioeconômica.

Acrescenta o parágrafo único do mesmo artigo que os projetos de lei complementares que tiverem por objetivo a divisão do território estadual em unidades regionais deverão ser instruídos com certidão atestando a existência das características legais fundamentais para as Regiões Metropolitanas e o resultado da audiência aos Municípios interessados.

A Constituição de Minas Gerais (artigo 42) também previu como requisito para instituir, por exemplo, as Regiões Metropolitanas critérios técnicos com-

9 Lei Complementar n. ${ }^{\circ} 760$, de 1 de agosto de 1994: estabelece diretrizes para a Organização Regional do Estado de São Paulo.

10 Lei Complementar n. ${ }^{\circ} 760 / 1994$, artigo 3. ${ }^{\circ}$, I a IV 
probatórios da realidade fática que origina a conurbação entre os Municípios limítrofes.

Segundo o artigo 44, a região metropolitana será instituída com base na Constituição Estadual e na avaliação (parecer técnico) de fatores como população e crescimento demográfico (com projeção quinquenal), grau de conurbação e movimentos pendulares da população ${ }^{11}$, atividade econômica e perspectivas de desenvolvimento e polarização da deficiência dos serviços públicos, em um ou mais Municípios, com implicação no desenvolvimento da região.

A Constituição Estadual mineira também atrela a inclusão de municípios em região metropolitana já criada à elaboração de estudo prévio $\left(\$ 2 .^{\circ}\right)$, que deverá acompanhar o projeto de lei complementar responsável pela formação da figura regional ( $\$ 1{ }^{\circ}$ do artigo 44 da Constituição de Minas Gerais), nos termos de lei complementar.

Coube à Lei Complementar n. ${ }^{\circ} 88$ de $2006^{12}$ disciplinar o procedimento de elaboração dos pareceres técnicos, previstos na Carta Constitucional. O parecer técnico que embasará a criação da Região Metropolitana (§ 1. ${ }^{\circ}$ do artigo $3^{\circ}$ ) será elaborado por instituição de pesquisa com notório conhecimento e experiência em estudos regionais e urbanos, a partir de informações fornecidas por fontes especializadas e acompanhará o projeto de lei responsável, sob pena de inconstitucionalidade $\left(\S 4 .^{\circ}\right.$ do artigo $3 .^{\circ}$ da Lei Complementar n. ${ }^{\circ}$ 88/2006). Da mesma forma, o parecer será obrigatório para incluir Município em região metropolitana já criada.

Segundo o artigo $3 .^{\circ}, \S 5 .^{\circ}$ e $\S 6 .^{\circ}$ da Lei Complementar n. ${ }^{\circ} 88$, há possibilidade dos municípios se manifestarem no processo de criação das regiões metropolitanas. A instituição de pesquisa responsável pelos estudos técnicos de criação das regiões metropolitanas encaminhará aos Municípios interessados, antes de concluir o parecer técnico, as informações coletadas e analisadas e lhes concederá tempo para manifestação.

Examinemos os requisitos necessários, obrigatórios, sem os quais as figuras regionais não serão criadas por lei complementar estadual. Para PEDRO ESTEVAM SERRANO, o legislador não está vinculado à criação das Regiões Metropolitanas, por exemplo, não está obrigado a editar lei complementar, que cria a região metropolitana. No entanto, se decidir realizar a função, deverá observar os requisitos da norma constitucional, sobretudo no que tange aos fins a serem

11 A terminologia "movimento pendular da população" foi utilizada pela publicação "Estudo da morfologia e hierarquia funcional da Rede Urbana Paulista e da Regionalização do Estado de São Paulo", publicação da Emplasa, Secretaria de Economia e Planejamento, Fundação Sistema Estadual de Análise de Dados, Seade, dezembro de 2010. Trata-se do deslocamento das pessoas entre as cidades da região por motivos de trabalho e estudo, por exemplo.

12 Lei Complementar n. ${ }^{\circ}$ 88/2006 (Minas Gerais), responsável pelas disposições gerais acerca da instituição e gestão de região metropolitana e o Fundo de Desenvolvimento Metropolitano. 
alcançados. Trata-se de competência legislativa positivamente vinculada, uma vez que terá o legislador autonomia para qualificar os fins e os pressupostos de fato respeitando os requisitos constitucionais: agrupamento de municípios limítrofes que exijam planejamento, organização e execução de funções públicas de interesses comuns. $\mathrm{O}$ autor admite a existência de inegável esfera autônoma de decisão do legislador complementar estadual para criar a Região Metropolitana. Contudo, a despeito deste campo discricionário e autônomo de decisão, surge outra competência vinculada quanto aos requisitos de criação da figura regional. Existem requisitos materiais (fáticos), formais e de conteúdo da norma constitucional que orientam o legislador infraconstitucional. Se eles não estiverem presentes, a lei complementar será inconstitucional.

São requisitos materiais, conforme o autor (SERRANO, 2009, p. 166-167), a existência de conurbação entre no mínimo três municípios limítrofes, (a.1) cuja natureza fática de seu agrupamento exija a realização de serviços comuns, (a.2) a serem planejados e executados na forma regional.

São requisitos formais a criação da figura regional por meio de Lei Complementar Estadual que, como terceiro requisito, deverá trazer o vínculo compulsório formado entre os Estados e Municípios na gestão de serviços e atividades de interesse de todos. Por sua vez, são considerados requisitos de conteúdo para a criação das figuras regionais, a existência dos vínculos compulsórios, previstos de forma implícita na previsão constitucional ( $33 .^{\circ}$ do artigo 25 ), entre o Estado e Município na gestão das funções públicas de interesse comum (SERRANO, 2009, p.169).

Mas, o que efetivamente caracteriza o vínculo compulsório? O agrupamento forçado de municípios limítrofes por meio de lei complementar estadual com o intuito de organizar, planejar e executar funções públicas de interesse comum (artigo 25, § 3. ${ }^{\circ}$ da Constituição Federal). De acordo com PeDro EsteVAM SERRANO (2009, p. 193), a instituição da Região Metropolitana implica a submissão dos Municípios a seus termos, independentemente de sua vontade.

Ainda que não seja atribuída ao Município a possibilidade de escolher integrar a região metropolitana, o vínculo compulsório pressupõe a garantia de que os municípios devem participar das decisões e ações regionais, em todas as fases da gestão do interesse comum, no papel e intensidade definido pelo legislador complementar estadual (SERRANO, 2009, p. 170).

A ideia é obtida como contraponto à noção de convênios ou consórcios entre entidades governamentais, vínculos jurídicos possíveis em razão do artigo 241 da Constituição Federal que prevê, por meio destas figuras, a gestão associada de serviços públicos. O vínculo consorcial está adstrito à vontade das partes envolvidas, no caso os Municípios, que poderão a qualquer momento se retirar do pacto celebrado. O consórcio pressupõe adesão autônoma das partes e não é veículo constitucional previsto para a instituição da Região Metropolitana (SERRANO, 2009, p. 193). 
Sustentam Pedro Estevam Serrano e Alâ̂r Caffé Alves (2011, p. 66) que se a Constituição Federal desejasse um vínculo voluntário entre os municípios não criaria uma disposição distinta, em outro Título da Constituição, que cuida estritamente da Organização do Estado. Vale adicionar as observações de AlaÔR CAFFÉ AlVES (2011, p. 66) no sentido de observar que o vínculo regional não pode ser criado pelo Estado de forma arbitrária, de acordo com sua vontade e escolha de qual município integrará a região metropolitana. A lei complementar está adstrita aos critérios materiais, ou seja, o município deve pertencer à realidade urbana conurbada comprovada, segundo algumas leis estaduais, por pareceres técnicos. Assim, a escolha dos municípios está vinculada às situações objetivas, descritas na hipótese normativa de cada figura regional, sob pena de inconstitucionalidade da lei complementar.

A existência de vínculo compulsório também foi acolhida pela jurisprudência em dois acórdãos julgados pelo STF (MENCIO, 2012, p. 427-446). O primeiro trata da ADIN 796-3 do Espírito Santo, publicada em 2/2/1998 e relatada pelo ministro NéRI DA SiLVEIRA. O segundo, da ADIN 1841-9 do Rio de Janeiro, publicada em 20/9/2002, relatada pelo ministro CARLOS Velloso. No primeiro caso, foi considerada inconstitucional a previsão da Constituição do Estado do Espírito Santo que determinava a anuência dos municípios com relação ao ingresso de regiões metropolitanas, por meio do plebiscito. No segundo caso, o STF considerou inconstitucional a previsão da Constituição do Rio de Janeiro que determinava a concordância prévia dos Municípios com relação à formação das Regiões Metropolitanas. Nos dois acórdãos, ficou decidido que o artigo $25, \S 3 .^{\circ}$ da Constituição Federal previu competência privativa dos Estados para disciplinar as Regiões Metropolitanas, sem que os Municípios tenham de manifestar sua vontade com relação à formação da região.

Além disto, os ministros argumentaram que o Estado não pode estabelecer (artigos 25, da Constituição Federal de 1988 e 11, do ADCT), requisitos não previstos pela Constituição Federal para criar Região Metropolitana.

Não há no texto constitucional determinação para a realização de plebiscito para compor o processo de formação das figuras regionais. Também foi invocado o vínculo compulsório entre os municípios da região a ser criada, o qual impede que um possa ser retirado por conta da discordância de seus munícipes.

Além dos parâmetros constitucionais, o legislador constituinte estadual poderá estabelecer outros requisitos que servem para orientar o exercício da competência legislativa do legislador constituinte. É por isto que RAFAEL Augusto Silva Domingues (2010, p. 160), afirma que os Estados-membros não são totalmente livres para escolher os municípios que integrarão a região metropolitana. O Município que não cumprir os pressupostos constitucionais que autorizam a criação das figuras regionais, isto é, a presença de conurbação urbana e de interesses comuns entre os municípios limítrofes, poderá questionar judicialmente seu ingresso na Região Metropolitana. Ressaltamos que cada 
um dos requisitos constitucionais previstos para a criação das Regiões Metropolitanas são igualmente aplicáveis às aglomerações urbanas e microrregiões.

\section{DIRETRIZES GERAIS ESTABELECIDAS PELO ESTATUTO DA METRÓPOLE (LEI FEDERAL N. ${ }^{\circ} 13089 / 2015$ )}

O Estatuto da Metrópole foi editado com base nos incisos XX do artigo 21, IX do artigo 23 e I do artigo $24, \mathrm{n}^{\circ} \S 3 .^{\circ}$, do artigo 25 e no artigo 182 da Constituição Federal ${ }^{13}$. Como dissemos anteriormente, a Lei Federal n. ${ }^{\circ} 13089 / 2015$ é aplicável às regiões metropolitanas, nos termos do seu artigo $1 .{ }^{\circ}, \S 1{ }^{\circ}$, I.

Por sua vez, no artigo $2 .^{\circ}$, o diploma federal tratou de definir de forma genérica o conteúdo de aglomeração urbana, metrópole e região metropolitana como "unidade territorial urbana constituída pelo agrupamento de 2 (dois) ou mais Municípios limítrofes, caracterizada por complementaridade funcional e integração das dinâmicas geográficas, ambientais, políticas e socioeconômicas; V - metrópole: espaço urbano com continuidade territorial que, em razão de sua população e relevância política e socioeconômica, tem influência nacional ou sobre uma região que configure, no mínimo, a área de influência de uma capital regional, conforme os critérios adotados pela Fundação Instituto Brasileiro de Geografia e Estatística - IBGE; VII - região metropolitana: aglomeração urbana que configure uma metrópole".

Isto significa dizer que, por força da competência concorrente, a lei federal estabeleceu critérios mínimos que deverão nortear a criação das regiões metropolitanas e aglomerações urbanas por parte de todos os Estados da federação. Isto não foi feito com relação à microrregião.

No que toca à metrópole, que por sua vez será transformada em região metropolitana, caso seja uma aglomeração urbana qualificada, os critérios adotados pelo IBGE para delimitar a região de influência de uma capital regional, levará em consideração os bens e serviços fornecidos pela cidade à região, abrangendo produtos industriais, educação, saúde, serviços bancários, comércio, empregos e outros itens pertinentes, e serão disponibilizados pelo IBGE na rede mundial de computadores (artigo 2. ${ }^{\circ}$, parágrafo único).

13 Artigo 21: "Compete à União: [...] XX - instituir diretrizes para o desenvolvimento urbano, inclusive habitação, saneamento básico e transportes urbanos; artigo 23. É competência comum da União, dos Estados, do Distrito Federal e dos Municípios: IX - promover programas de construção de moradias e a melhoria das condições habitacionais e de saneamento básico; artigo 24. Compete à União, aos Estados e ao Distrito Federal legislar concorrentemente sobre: I - direito tributário, financeiro, penitenciário, econômico e urbanístico"; artigo 182: "A política de desenvolvimento urbano, executada pelo Poder Público municipal, conforme diretrizes gerais fixadas em lei, tem por objetivo ordenar o pleno desenvolvimento das funções sociais da cidade e garantir o bem-estar de seus habitantes". 
De outro lado, de acordo com o artigo 15, a região metropolitana instituída mediante lei complementar estadual que não atenda o disposto no inciso VII do caput do artigo $2 .^{\circ}$ desta Lei será enquadrada como aglomeração urbana para efeito das políticas públicas a cargo do governo federal, independentemente de as ações nesse sentido envolverem ou não transferência de recursos financeiros. Assim, a região metropolitana será qualificada como aglomeração urbana metropolitana e a aglomeração urbana, como unidade territorial urbana constituída pelo agrupamento de 2 (dois) ou mais Municípios limítrofes, caracterizada por complementaridade funcional e integração das dinâmicas geográficas, ambientais, políticas e socioeconômicas. Neste sentido, por força da lei federal, as figuras estão bem próximas, tal como foi disposto anteriormente pela doutrina e pelas leis estaduais.

Por outro lado, o Capítulo Il é destinado à disciplinar a instituição por parte dos Estados das Regiões Metropolitanas e das aglomerações urbanas, reunindo conjunto de dispositivos legais que condicionam a atuação dos Estadosmembros que por força constitucional tem a faculdade de criar referidas figuras regionais. Este regime é aplicável às microrregiões, embora seu conceito não seja delimitado pelos dispositivos da lei.

Nos termos do artigo $3 .^{\circ}$, os Estados, mediante lei complementar, poderão instituir regiões metropolitanas e aglomerações urbanas, constituídas por agrupamento de Municípios limítrofes, para integrar a organização, o planejamento e a execução de funções públicas de interesse comum.

A Lei Federal, por força do artigo $4^{\circ}$, inovou constitucionalmente e admitiu a criação de regiões metropolitanas e aglomerações urbanas que envolvam municípios pertencentes a mais de um Estado, hipótese não prevista expressamente pela Constituição Federal, determinando que a formalização deste arranjo metropolitano seja feito mediante a aprovação de leis complementares pelas Assembleias Legislativas de cada um dos Estados envolvidos. O parágrafo único ressaltou que até a aprovação das leis complementares previstas no caput deste artigo por todos os Estados envolvidos, a região metropolitana ou a aglomeração urbana terá validade apenas para os Municípios dos Estados que já houverem aprovado a respectiva lei.

E por fim, o Estatuto da Metrópole tratou no artigo 5. ${ }^{\circ}$ incisos I a IV do conteúdo básico das leis complementares estaduais responsáveis pela criação das regiões metropolitanas e aglomerações urbanas. Deste modo, as leis complementares deverão prever, no mínimo: I - os Municípios que integram a unidade territorial urbana; II - os campos funcionais ou funções públicas de interesse comum que justificam a instituição da unidade territorial urbana, III - a conformação da estrutura de governança interfederativa, incluindo a organização administrativa e o sistema integrado de alocação de recursos e de prestação de contas; e IV - os meios de controle social da organização, do planejamento e da execução de funções públicas de interesse comum. 
Isto significa que no mínimo, como diretriz geral aplicável a todos os Estados-membros, os conteúdos das leis complementares seguirão estes parâmetros, sem prejuízo de outros acrescentados pelos Estados-membros. Neste rol mínimo, identificamos a preocupação do legislador federal em definir os municípios envolvidos na estrutura regional e as funções que serão geridas de forma compartilhada (transporte, uso e ocupação do solo, saneamento básico), em razão das peculiaridades da região, justamente pela incapacidade de ser resolvido de forma isolada por um ou outro município da região. Neste caso, a interpretação deverá levar em consideração o critério definido no artigo 2. ${ }^{\circ}$, II que considera função pública de interesse comum a política pública ou ação nela inserida cuja realização por parte de um Município, isoladamente, seja inviável ou cause impacto em Municípios limítrofes. Além disto, a lei complementar deverá tratar da forma de gestão do ponto de vista administrativo, por meio da criação de autarquia territorial (agências) com apoio dos conselhos deliberativos e consultivos e dos instrumentos de participação popular, como por exemplo previsão de consultas e audiências públicas e participação da sociedade civil nos conselhos deliberativos e consultivos.

É importante ressaltar, tal como previsto pelo regime das leis estaduais complementares, que os critérios técnicos que justificam a escolha dos municípios limítrofes integrantes dos vários tipos de arranjos regionais (existência ou não de conurbação, grau expressivo de articulação funcional e integração entre as dinâmicas geográficas, ambientais, políticas e socioeconômicos dos municípios envolvidos, relevância nacional) deverão acompanhar a exposição de motivos da lei complementar responsável pela criação da figura regional.

Vale ressaltar, que este regime é aplicável às microrregiões (no que couber - artigo $\left.1 .^{\circ}, \S 1 .^{\circ}, I\right)$, embora sua definição não tenha sido delimitada pela lei federal.

\section{A CONSTITUCIONALIDADE DAS PREVISÕES DO ESTATUTO DA METRÓPOLE PARA CRIAÇÃO DAS FIGURAS REGIONAIS}

O presente item é destinado à reflexão sobre a possibilidade de lei infraconstitucional elaborada pela União cuidar do tema metropolitano, em razão do artigo 25, §3. ${ }^{\circ}$ atribuir competência expressa aos Estados-membros para tratar do assunto. Ao questionarmos a compatibilidade entre o artigo 25, § 3 . da Constituição Federal e os artigos 1. $.^{\circ}, 2 .^{\circ}, 3 .^{\circ}, 4 .^{\circ}, 5^{\circ}$ e 15 do Estatuto da Metrópole não significa que deixaremos de interpretar os dispositivos legais conforme a Constituição Federal. Vale dizer, o fato de questionarmos a constitucionalidade, não implicará na defesa da tese sobre a inconstitucionalidade dos dispositivos da lei federal, pois utilizaremos a técnica da Interpretação conforme a Constituição. 
Nas lições do professor Luís RobERTO BARROSO (p. 302), este princípio tem como propósito atribuir sentido às normas infraconstitucionais, da maneira que melhor realize os valores e fins constitucionais. De acordo com o professor, entre as interpretações possíveis da norma, deve-se escolher aquela que tem mais coerência e pertinência com a Constituição Federal. Deste modo, o intérprete de um lado preserva a validade desta lei e de outro elimina a interpretação contrária ao sentido constitucional, que poderia comprometer a sua permanência no sistema jurídico.

De fato, não deveremos recair no exagero interpretativo, no sentido de imprimir uma interpretação à norma jurídica a qualquer custo "salvando a lei" em detrimento do disposto na Constituição ou contrariando seu sentido para constitucionalizá-la de qualquer maneira, parafraseando a feliz expressão de InOCÊNCIO MÁrTiRes COElHO (Mendes E GONET, 2009, p. 141) ${ }^{14}$.

Deste modo, partindo da interpretação conforme a Constituição, discutiremos as possíveis interpretações das normas, procurando conciliar o sentido e alcance dos dispositivos legais ao conteúdo das normas constitucionais.

$\mathrm{Na}$ década de 90, por ocasião da discussão do Estatuto da Cidade, Clementina de Ambrosis (Regiões Metropolitanas, 2001), recordou que as diretrizes gerais para a criação das Regiões Metropolitanas foram tratadas pelo Projeto de Lei n. ${ }^{\circ} 5.788$ de 1990. No entanto, foi redigido pela Comissão de Constituição e Justiça um substitutivo em 28/11/2000 pelo deputado Iranildo Leitão, que o retirou, uma vez que a criação e a instituição das Regiões Metropolitanas foram consideradas competência exclusiva do Estado (artigo 25, $\S 3 .^{\circ}$ da Constituição).

Em razão da ausência de tratamento das regiões metropolitanas por meio do Estatuto da Cidade, coube aos Estados por meio de suas Leis Complementares normatizar os requisitos de criação das figuras regionais.

Entretanto, em termos legislativos o cenário sofreu modificações em 2004, quando foram realizados seminários e audiências públicas na Câmara dos Deputados, que culminaram com a proposição do Projeto de Lei n. ${ }^{\circ}$ 3.460/2004, do deputado federal Walter FelDMAnN, denominado Estatuto da Metrópole, cujo objetivo era tratar a questão metropolitana em âmbito federal.

Curso de Direito Constitucional. Co-autoria com Gilmar Ferreira Mendes e Paulo Gustavo Gonet Branco. Saraiva, p. 141. Neste sentido, afirma InOCÊnCio MárTires CoelHo ao dispor sobre presunção de constitucionalidade das leis: "Essa prudência, por outro lado, não pode ser excessiva, a ponto de induzir o intérprete a salvar a lei à custa da Constituição, nem tampouco a contrariar o seu sentido inequívoco, para constitucionalizá-la de qualquer maneira. No primeiro caso, porque isso implicaria interpretar a Constituição conforme a lei e, assim, subverter a hierarquia das normas; no segundo, porque toda conformação exagerada implica, no fundo, usurpar tarefas legislativas e transformar o intérprete em legislador positivo, na exata medida em que a lei resultante dessa interpretação conformadora só nas aparências, em verdade seria substancialmente distinta, em sua letra como no seu espírito, daquela que resultou do trabalho legislativo". 
Apesar de competir ao Estado criar os arranjos regionais, a União não foi excluída do planejamento regional de ordenação do território, por força do artigo 21, IX, XV, XX da Constituição Federal.

A ela compete com exclusividade instituir diretrizes ao desenvolvimento urbano, elaboração e execução de planos nacionais e regionais de ordenação do território e de desenvolvimento econômico e social, o desenvolvimento de instrumentos para organização e manutenção de serviços oficiais de estatística, geografia, geologia e cartografia em âmbito nacional.

Em abril de 2012, a tramitação do Projeto de Lei n. ${ }^{\circ}$ 3.460/2004 foi reativada com a criação da Comissão Especial que elaborou um parecer ao projeto, tendo o deputado ZeZÉu Ribeiro (PT/BA) como relator. Entre os anos de 2013/2014, após a realização de várias audiências públicas estaduais pela Câmara dos Deputados, a lei foi discutida e aprovada no Senado Federal. No entanto, sua redação sofreu vetos presidenciais, sobretudo, em relação aos dispositivos legais destinados à criação de fundos para aprimoramento da gestão metropolitana, resultando na publicação da Lei Federal em janeiro de 2015.

Diante do exposto, indagamos: um diploma federal poderia instituir diretrizes gerais para toda e qualquer figura regional instituída no Estado federado Brasileiro? À luz da divisão constitucional de competências a resposta é afirmativa. A União participa do planejamento urbano nacional, conferindo as diretrizes gerais para os planejamentos regionais e locais.

Destarte, partindo desta premissa e utilizando as lições de RiCARDO MARCONDES MARTINS (2009/2010) ao tratar de normas gerais em direito urbanístico, defendemos a constitucionalidade do Estatuto da Metrópole, apesar de competir especificamente aos Estados-membros criar as regiões metropolitanas, aglomerações urbanas e microrregiões através de Leis complementares. Segundo o autor, o preenchimento do conteúdo das normas gerais da União e dos Estados decorre da ponderação de princípios (prevalece o da segurança jurídica) bem como do município (prevalece o da igualdade). Isto significa que no exercício da competência do artigo 24 da Constituição Federal, o legislador infraconstitucional deverá verificar o princípio que irá predominar.

Priorizado o da igualdade, as peculiaridades urbanas de cada Estado deveriam ser observadas em suas legislações para definir as figuras regionais. Esta foi a opção aplicada até a edição do Estatuto da Metrópole, gerando disparidades em relação à realidade urbana do país, uma vez que os parâmetros para criar, por exemplo, a Região Metropolitana de São Paulo não são os mesmos da Região Metropolitana de Manaus. Deste modo, com a aprovação do Estatuto da Metrópole haverá coerência em relação à aplicação das regras de competência constitucionais, pois o interesse nacional, em nome da segurança jurídica será priorizado. A lei federal ao reconhecer os parâmetros nacionais, fixados como patamar mínimo para todos os Estados-membros criarem suas figuras regionais, estabeleceu em nível nacional segurança jurídica e planejamento 
urbano uniforme e equilibrado em todo país, reduzindo as disparidades urbanas, decorrente do fenômeno da conurbação.

Não houve ingerência na competência exclusiva prevista no artigo $25, \S$ 3. ${ }^{\circ}$ da Constituição Federal ao tratar da criação pelos Estados-membros das figuras regionais. O Estatuto da Metrópole não obriga, apenas fornece parâmetros gerais, caso o legislador Estadual opte por instituir as figuras regionais. Caso contrário, o Estado apenas deixará de criar as figuras, sem desrespeitar a partilha constitucional de competências.

$\mathrm{Na}$ hipótese dos legisladores estaduais exercerem suas competências por meio de suas Leis Complementares, deverão adotar os critérios gerais da União para criar e administrar o planejamento regional. Diante do Estatuto da Metrópole, deverão suplementar estes comandos regionais, no que tange às suas especificidades, decidindo se criarão ou não suas realidades metropolitanas. Caso decidam fazê-lo, no mínimo deverão respeitar estas diretrizes ${ }^{15}$.

Em razão da ausência do Estatuto da Metrópole até janeiro de 2015, coube aos legisladores estaduais por meio de normas complementares legislarem suplementarmente, de forma ampla sobre a criação das figuras regionais, oferecendo parâmetros e tratamentos díspares entre as regiões metropolitanas pelo país.

A interpretação constitucional parte, neste aspecto, da combinação entre os dispositivos do artigo $25, \S 3 .^{\circ}$ e os artigos $24, \mathrm{I}, \S 1 .^{\circ}, \S 2 .^{\circ}, \S 3 .^{\circ}, \S 4 .^{\circ} \mathrm{da}$ Constituição Federal. De fato, a Constituição delimitou como competência exclusiva do Estado-membro a instituição das regiões metropolitanas, aglomerações urbanas e microrregiões. Por outro lado, não podemos deixar de observar que a criação das figuras regionais está inserida em um contexto de desenvolvimento urbano, justamente por serem fruto do fenômeno da conurbação, resultado da combinação entre as cidades que nascem e expandem seus limites em relação aos municípios. Desta forma, a criação e a disciplina dos arranjos regionais estão condicionadas ao direito urbanístico. É por isto que a competência dos Estados prevista no artigo 25, § 3. ${ }^{\circ}$, deve ser interpretada em conjunto com o artigo 24, que dispõe sobre a competência concorrente dos entes federados em matéria urbanística. Enquanto, a União não tratava dos aspectos gerais urbanos destas figuras regionais, cada Estado-membro, por força do $\S 3 .^{\circ}$ do artigo 24, cuidou de exercer plenamente suas competências e estabelecer seus requisitos para criação dos arranjos regionais. Com a edição da lei federal, muitos dos dispositivos das leis complementares estaduais poderão deixar de produzir seus efeitos, em razão da suspensão promovida pelo

15 Artigo 24: "Compete à União, aos Estados e ao Distrito Federal legislar concorrentemente sobre: I - direito tributário, financeiro, penitenciário, econômico e urbanístico; $§ 1{ }^{\circ}$ - No âmbito da legislação concorrente, a competência da União limitar-se-á a estabelecer normas gerais. § $2 .^{\circ}$ - A competência da União para legislar sobre normas gerais não exclui a competência suplementar dos Estados. $§ 3 .^{\circ}$ - Inexistindo lei federal sobre normas gerais, os Estados exercerão a competência legislativa plena, para atender a suas peculiaridades". 
Estatuto da Metrópole, desde que não sejam compatíveis com o seu conteúdo. A partir da entrada em vigor da Lei n. ${ }^{\circ}$ 13.089/2015, a disciplina urbanística de criação das figuras regionais está atrelada às condições gerais previstas em suas disposições legais.

Por isto consideramos constitucional a norma geral federal, que uniformiza os critérios de criação das figuras regionais e contribui com a harmonia do planejamento urbano em todo o território nacional.

Para NelSON SAULe JúNIOR (Direito Urbanístico, 2007, p. 96-97) a União tem competência para dispor sobre as diretrizes gerais do desenvolvimento urbano, matéria diretamente relacionada à realidade metropolitana, da mesma forma que influencia a criação de Estados e Municípios (artigo 18 , $33 .{ }^{\circ}$ e $\S 4 .^{\circ}$ da Constituição Federal), entidades integrantes das Regiões Metropolitanas. A União deverá tratar do papel, da finalidade, dos critérios para criação estabelecidos nas leis complementares estaduais e as atribuições das figuras regionais urbanas. De acordo com o autor (SAULE, 2007, p. 97), os assuntos das regiões estaduais administrativas (regiões metropolitanas, aglomerações urbanas e microrregiões) são assuntos de interesse nacional como a política nacional de desenvolvimento urbano, habitação, saneamento ambiental, mobilidade e transporte urbano, que demandam conjugação de esforços envolvendo a União, os Estados e os Municípios no planejamento e execução das funções públicas de interesse comum.

O Estatuto da Metrópole cumpre o mesmo propósito das demais leis federais urbanísticas, ao viabilizar a elaboração e a execução de planos nacionais e regionais de ordenação do território e fixar diretrizes da política nacional de planejamento regional urbano.

O documento aborda normas aplicáveis a todo território nacional, que proporcionarão à União, ao lado dos Estados e Municípios integrantes das figuras regionais, a definição dos critérios para a organização regionalizada do território nacional, assegurando o equilíbrio do desenvolvimento dessas unidades e do bem-estar da população.

Em suma, com base na divisão constitucional de competências, a lei federal não amesquinha a competência legislativa exclusiva do Estado, pois a competência para decidir em última análise se haverá criação ou não das regiões metropolitanas, aglomerações urbanas e mesmo em face dos critérios fixados em lei nacional, permanece com os Estados.

Ao lado destas questões, alguns poderiam desconfiar da constitucionalidade do artigo $4 .^{\circ}$ da Lei Federal, ao permitir que exista região metropolitana ou aglomeração urbana que envolva municípios pertencentes a mais de um Estado, pois o sentido amplia a previsão inicialmente definida pelo artigo 25 , $\S 3 .^{\circ}$ da Constituição Federal. Esta impressão acerca da inconstitucionalidade é passageira, pois compete à União Federal nos termos do artigo 24, I editar normas gerais sobre direito urbanístico, inclusive, no que toca aos aspectos de desenvolvimento urbano, ampliando o sentido da abrangência das regiões, 
uma vez que o próprio dispositivo constitucional (artigo $25, \S 3 .^{\circ}$ ) não estabeleceu uma redação restritiva. Neste caso, é possível ampliar o sentido da norma constitucional, prevendo a existência de figuras regionais que envolvam mais de um Estado da Federação, justifica-se a existência de diretrizes gerais que cuidem da abrangência de mais de um Estado e seus municípios conurbados, realidade urbana que repercute em interesses de grande impacto nacional. É importante ressaltar que o Estatuto respeitou inclusive os Poderes legislativos de cada um dos Estados participantes da região, pois todas as Assembleias Legislativas envolvidas deverão aprovar a criação do arranjo regional. Caso a aprovação não seja feita, a criação da região metropolitana ou aglomeração urbana só terá validade para os municípios dos Estados que já houverem aprovado a respectiva lei.

Até o presente momento, ainda não foram criadas regiões metropolitanas ou aglomerações urbanas que envolvam Municípios pertencentes a mais de um Estado da federação.

$\mathrm{Na}$ realidade, podemos destacar rapidamente dois casos que tratam de figuras conexas a este fenômeno, que contribuem para reflexão sobre a questão. Contudo, ainda não reunimos juridicamente elementos suficientes para enquadrar os dois fenômenos na hipótese do artigo $4^{\circ}$ do Estatuto da Cidade.

A primeira hipótese refere-se à Região Integrada de Desenvolvimento Econômico de Brasília (RIDE), instituída pela Lei Complementar 94/1998, embasada na Constituição Federal, artigos 21, IX e XX e 43. A área da RIDE compreende além do Distrito Federal, 22 municípios, dos quais 19 estão situados no Estado de Goiás e 3 no Estado de Minas Gerais ${ }^{16}$ e foi instituída para realizar o planejamento conjunto de serviços públicos comuns a esses entes, em especial em infraestrutura e geração de empregos ${ }^{17}$.

Importante frisarmos que o Distrito Federal não forma uma região metropolitana, pois o artigo 32 da Constituição Federal não admite divisão de seu território em municípios, requisito essencial para constituição de região metropolitana. Neste sentido, foi criada a RIDE, que não se confunde com região

16 Os municípios goianos são Abadiânia, Água Fria de Goiás, Águas Lindas de Goiás, Alexânia, Cabeceiras, Cidade Ocidental, Cocalzinho de Goiás, Corumbá de Goiás, Cristalina, Formosa, Luziânia, Mimoso de Goiás, Novo Gama, Padre Bernardo, Pirenópolis, Planaltina, Santo Antônio do Descoberto, Valparaíso de Goiás e Vila Boa e os municípios mineiros são Buritis, Cabeceira Grande e Unaí incluídos na área da RIDE.

17 Projeto: Governança Metropolitana no Brasil. Relatório: Caracterização e Quadros de Análise Comparativa da Governança Metropolitana no Brasil Arranjos Institucionais de Gestão Metropolitana. Instituição: Companhia de Planejamento do Distrito Federal (CODEPLAN) 15 de março de 2013 Relatório de Pesquisa Coordenadora Estadual do Projeto Cárita da Silva Sampaio - Técnica da CODEPLAN Equipe Estadual Giuliana Corrêa - Técnica da codeplan Francisca PaZ - adrmbh Tamile Dias - Bolsista codeplan. Publicação do IPEA. 
metropolitana e envolve três entidades federativas: Distrito Federal, Estado de Minas Gerais e Goias.

Inicialmente, o projeto de lei do Estatuto da Metrópole permitia por força do artigo 19 a integração do Distrito Federal à região metropolitana ou aglomeração urbana, aplicando-se a ele o conteúdo do artigo $4^{\circ}$. Contudo, o artigo foi vetado, por meio da seguinte mensagem de veto: "Ao tratar de regiões metropolitanas, aglomerações urbanas e microrregiões, a Constituição faz referência, em seu artigo 25, § $3 .^{\circ}$, a agrupamento de Municípios. Neste sentido, as inclusões no escopo do Estatuto da Metrópole de território de um único Município isolado e do Distrito Federal não encontrariam amparo constitucional. Em relação ao Distrito Federal, o instrumento de cooperação federativa adequado é a Região Integrada de Desenvolvimento Econômico RIDE, prevista no artigo 43 da Constituição. Está já foi, inclusive, criada pelo Decreto n. ${ }^{\circ} 2.710$, de 4 de agosto de 1998 - substituído pelo Decreto n. ${ }^{\circ}$ 7.469, de 4 de maio de 2011 - que regulamenta a Lei Complementar n. ${ }^{\circ} 94$, de 19 de fevereiro de $1998^{\prime \prime}$.

Ao promovermos a interpretação sistemática da Constituição Federal, encontramos respaldo para sustentar juridicamente as razões do veto presidencial.

A primeira parte do artigo 32 da Constituição Federal veda a divisão do Distrito Federal em Municípios. Assim, não existe do ponto de vista jurídico, por força de mandamento expresso da Constituição, Município no Distrito Federal.

Dispõe o artigo 10 da Lei Orgânica do Distrito Federal que sua organização é feita por meio de Regiões Administrativas visando à descentralização administrativa, à utilização racional de recursos para o desenvolvimento socioeconômico e à melhoria da qualidade de vida. De acordo com o artigo 11, as administrações regionais integram a estrutura administrativa do Distrito Federal, mas cada região contará com um Conselho de Representantes Comunitários, com funções consultivas e fiscalizadoras.

Por outro lado, ao examinarmos o artigo 25, § 3. ${ }^{\circ}$, da Constituição Federal verificamos que as Regiões Metropolitanas são constituídas por agrupamentos de municípios limítrofes, para integrar a organização, o planejamento e a execução de funções públicas de interesse comum. Do cotejo dos dois dispositivos constitucionais, concluímos não haver possibilidade jurídica de constituir as figuras regionais no Distrito Federal. Assim, por força dos argumentos constitucionais expostos, qualificamos o Distrito Federal como RIDE e não como Região Metropolitana, embora sua organização administrativa envolva mais de dois entes federados, tal como a proposta do artigo $4 .^{\circ}$ do Estatuto da Metrópole.

Com relação à segunda hipótese, embora não tenha sido criada institucionalmente a Região Metropolitana abarcando os Estados de Minas Gerais, São Paulo e Rio de Janeiro, até por ausência dos requisitos constitucionais, trazemos o caso para reflexão justamente por envolver entre os três Estados 
da Federação o enfrentamento comum da gestão da bacia hidrográfica do $\mathrm{Pa}$ raíba do Sul, em razão da crise hídrica enfrentada pelos três entes federados.

Em 27/11/2014 ${ }^{[18]}$, o Supremo Tribunal Federal, por força de decisão judicial promoveu a mediação entre os governos dos três Estados-Membros, afetados pela crise hídrica, para promoção de solução conjunta nos projetos de transposição das águas interterritoriais. Por força desta decisão, no mês de março deste ano, os representantes destes Estados fecharam acordo para gestão conjunta da Bacia do Rio Paraíba do Sul. A convenção só entrará em vigor após o final do período de estiagem severa na Bacia e também após a construção do documento de resolução conjunta da ANA e dos órgãos responsáveis pela gestão de reservatórios hídricos nos três estados.

Apesar de não estarmos formalmente diante de uma Região Metropolitana, identificamos um caso emblemático na jurisprudência brasileira que enfrenta pela primeira vez a mediação envolvendo o guardião da Constituição em torno de problemas de cooperação federativa, que diz respeito à gestão da função pública comum de abastecimento de água para a população dos três estados federados.

E por fim, formulamos um questionamento acerca da opção do legislador no sentido de não definir os parâmetros mínimos por lei federal das microrregiões no Brasil, ainda que o diploma legal alcance esta figura regional. Diante desta questão, podemos formular a seguinte indagação: Levando em consideração o princípio da igualdade, é constitucional a previsão da lei federal que opte apenas por definir regiões metropolitanas e aglomerações urbanas, sem, no entanto, tratar como diretriz geral dos contornos das microrregiões? Qual o critério que autoriza a distinção de tratamento conferida às três figuras regionais pelo Estatuto da Metrópole?

Com base nos sábios ensinamentos do professor CELSO ANTÔNIO BANDEIRA DE MeLLO (2011, p. 47) haverá ofensa ao preceito constitucional da isonomia quando estivermos diante das seguintes hipóteses: "I - A norma singulariza atual e definitivamente um destinatário determinado, ao invés de abranger uma categoria de pessoas, ou uma pessoa futura e indeterminada; II - A norma adota como critério discriminador, para fins de diferenciação de regimes, elemento não residente nos fatos, situações ou pessoas por tal modo desequiparadas, III - A norma atribuiu tratamentos jurídicos diferentes em atenção a fator de discrímen adotado que, entretanto, não guarda relação de pertinência lógica com a disparidade de regimes outorgados; IV - A norma supõe relação de pertinência lógica existente em abstrato, mas o discrímen estabelecido conduz a efeitos contrapostos ou de qualquer modo dissonantes dos interesses prestigiados constitucionalmente V - A interpretação da norma extrai dela distinções, discrimens, desequiparações que não foram professadamente assumidos por 
ela de modo claro, ainda que por via implícita". Diante dos critérios apontados pelo professor CELSO ANTÔNIO BANDEIRA DE MELLO, poderemos justificar a diferença de tratamento conferida pelo Estatuto da Metrópole em relação às microrregiões, baseados na escolha do fator de distinção que guarda relação de pertinência lógica com a disparidade de regimes outorgados pela lei. Assim, como forma de conferirmos ao diploma legal uma interpretação conforme a constituição, entendemos que existe uma razão lógica e constitucional que justifique a diferença de tratamento, autorizando o Legislador Estadual a criar os parâmetros de criação das microrregiões de forma plena por meio de sua lei complementar.

Ao analisarmos os dispositivos constitucionais que tratam da repartição de competências federativas, percebemos que, neste caso, o princípio da igualdade deverá prevalecer em detrimento da segurança jurídica. Ao priorizar a igualdade, o Estatuto da metrópole preferiu estimular a aplicação do $\S 3 .^{\circ}$ do artigo $24 \mathrm{da} \mathrm{CF}$, por reconhecer que cada Estado tem suas peculiaridades regionais na definição de suas microrregiões, que em razão de sua área de influência não justifica amplo tratamento em nível nacional, permitindo, portanto, o exercício de competência legislativa plena por parte dos Estados.

Já verificamos que o grau de complexidade e tangenciamento da malha urbana entre os municípios das microrregiões é inexistente, uma vez que as cidades integrantes permanecerão nos limites de seus Municípios que contarão com áreas rurais e urbanas, deixando de apresentar entre si a conurbação.

Justamente em razão desta característica, o legislador ordinário optou por não fixar critérios gerais para definição destas figuras, uma vez que não haveria interferência acentuada no desenvolvimento urbano nacional a ponto de justificar em a fixação de critérios uniformes por meio de uma lei federal.

Desta forma, o Estatuto da Metrópole obedeceu ao comando constitucional que trata das competências concorrentes, deixando a liberdade maior para os Estados atuarem em termos de suas peculiaridades, no ato da criação de suas próprias microrregiões, mantendo, portanto, a constitucionalidade do Estatuto da Metrópole.

\section{CONCLUSÕES}

O intuito do artigo foi refletir sobre a constitucionalidade das disposições introduzidas pelo Estatuto da Metrópole responsáveis pela definição dos critérios de criação das regiões metropolitanas, aglomerações urbanas e microrregiões, nos termos da competência constitucional exclusiva (artigo 25, § 3..$^{\circ}$ atribuída aos Estados-Membros para instituir os arranjos regionais.

O artigo levantou três hipóteses da Lei Federal n. ${ }^{\circ} 13089 / 2015$ que poderiam suscitar questionamentos acerca de sua constitucionalidade. A primeira refere-se à viabilidade da União fixar requisitos gerais para todos os Estados- 
membros instituírem as figuras regionais. A segunda diz respeito à criação de regiões metropolitanas e aglomerações urbanas que envolvem municípios pertencentes a mais de um Estado da federação. E por fim, a terceira questão diz respeito à distinção de tratamento estabelecida pelo legislador federal ao fixar requisitos apenas para instituição das regiões metropolitanas e aglomerações urbanas, em detrimento das microrregiões, embora estenda os efeitos da lei para este tipo de arranjo federativo.

Em suma, com base na divisão de competências constitucionais verificamos que as três hipóteses normativas são constitucionais. No primeiro caso, apesar da Constituição prever como competência exclusiva dos Estados-Membros a criação das figuras regionais, a interpretação deverá levar em consideração a articulação do artigo 25, §3. ${ }^{\circ}$ com os artigos 21, XX e 24 da Constituição Federal, que condicionam o tratamento das figuras regionais à realidade urbana. Assim, enquanto não existia o Estatuto da Metrópole elaborado pela União, competia aos Estados, com base no artigo 24, §3. ${ }^{\circ}$, legislar sobre os requisitos de criação das regiões metropolitanas, aglomerações urbanas e microrregiões. A partir da vigência deste diploma federal, coube à União estabelecer as normas gerais responsáveis pela disciplina da matéria, sem esvaziar a competência dos Estados que poderão utilizar as diretrizes federais para complementar suas disposições, desde que seja no âmbito de seu interesse regional.

Por sua vez, no que tange à existência de região metropolitana ou aglomeração urbana que envolva municípios pertencentes a mais de um Estado, apesar da ampliação da hipótese não estamos diante de violação do artigo 25, §3. ${ }^{\circ}$ da Constituição Federal, pois com base nas diretrizes gerais de direito urbanístico compete à União ampliar o sentido das várias combinações regionais existentes dentro da disciplina de desenvolvimento urbano nacional.

E por fim, no que diz respeito à opção do legislador no sentido de não definir os parâmetros mínimos por lei federal das microrregiões no Brasil, ainda que o diploma legal alcance esta figura regional, entendemos que a omissão legislativa não foi inconstitucional, ou seja, não comprometeu o tratamento diferenciado em relação às regiões metropolitanas e aglomerações urbanas, em face do princípio da igualdade. Na verdade, entendemos que à luz deste princípio, que é possível justificar a diferença de tratamento conferida pelo Estatuto da Metrópole em relação às microrregiões, baseados na escolha do fator de distinção que guarda relação de pertinência lógica com a disparidade de regimes outorgados pela lei. Assim, como forma de conferirmos ao diploma legal interpretação conforme a constituição, sustentamos a existência de uma razão lógica e constitucional que justifique a diferença de tratamento, autorizando o legislador estadual a criar os parâmetros de criação das microrregiões de forma plena, por meio de sua lei complementar, uma vez que a criação das microrregiões apresenta um espectro de abrangência de desenvolvimento urbano menor do que as outras duas figuras, razão que justifica seu tratamento específico no âmbito do interesse regional de cada Estado da federação. 


\section{BIBLIOGRAFIA}

Alves, AlaÔR CAFfÉ (1998). Regiões metropolitanas, aglomerações urbanas e microrregiões: novas dimensões constitucionais da organização do Estado Brasileiro. Temas de Direito Ambiental e Urbanístico - Max Limonad - Advocacia Pública e Sociedade II (3), pp. 11-49.

Alves, Alâ̂R Caffé (2011). Regiões metropolitanas, aglomerações urbanas e microrregiões. Novas dimensões constitucionais da organização do Estado Brasileiro. Revista de Direito Ambiental 6 (21), jan.-mar., São Paulo: RT.

Ambrosis, Clementina de (2001). Regiões metropolitanas, aglomerações urbanas e microrregiões, in Mariana Moreira (Coord.), Estatuto da Cidade. São Paulo: CEPAM.

Araujo, Luiz Alberto David \& Nunes Junior, Vidal Serrano (2014). Curso de Direito Constitucional, ed. 19. São Paulo: Verbatim.

Barroso, Luiz Roberto (2011). Curso de Direito Constitucional Contemporâneo, Os conceitos fundamentais e a construção do novo modelo. 2 ed., 2. ${ }^{\circ}$ tiragem. São Paulo: Saraiva.

Covilla Martínez, Juan Carlos (2010). Las Administraciones Metropolitanas. Bogotá: Universidad Externado de Colombia.

Da Cunha Ferraz, Anna CÂndida (1979). Poder Constituinte do Estado-membro. Revista dos Tribunais, p. 19

Domingues, Rafael Augusto Silva (2010). A competência dos Estados-Membros no Direito Urbanístico, Limites da Autonomia Municipal. Belo Horizonte: Fórum.

Farias, Talden \& Correia, Arícia Fernandes (2014). Regionalismo como uma nova perspectiva para o federalismo brasileiro: o leading case relativo à Região Metropolitana do Rio de Janeiro. Revista Magister de Direito Ambiental e Urbanístico. Dez./jan., p. 5-39.

Ferrari, Regina Maria Macedo Nery (2005). Direito Municipal, 2 ed. São Paulo: RT.

Ferreira, Aurélio Buarque de Holanda (1994). Novo Dicionário Aurélio da Língua Portuguesa, 2 ed. Rio de Janeiro: Nova Fronteira.

Ferreira Filho, Manoel Gonçalves (1999). A democracia possível, 2 ed. São Paulo: Saraiva.

Governo do Estado de São Paulo (2008). Reorganização da Região Metropolitana de São Paulo consolida novo sistema de gestão. Publicação da Secretaria de Desenvolvimento Metropolitano de São Paulo e EMPLASA. São Paulo: Imprensa Oficial. 
Governo do Estado de São Paulo (2011). Rede urbana e regionalização do Estado de São Paulo. Publicação EMPLASA, SEADE, Secretaria de Planejamento e Desenvolvimento Regional e Secretaria de Desenvolvimento Metropolitano do Governo de São Paulo. São Paulo: Imprensa Oficial.

Governo do Estado de São Paulo (2011). Região Metropolitana do Vale do Paraíba e Litoral Norte. Publicação da Secretaria de Desenvolvimento Metropolitano de São Paulo e EMPLASA. São Paulo: Imprensa Oficial.

LefÉvre, CHRISTIAN (2008). Governar as metrópoles: questões, desafios e limitações. Cadernos Metrópole 11 (22), jul.-dez. São Paulo.

Machado, Gustavo Gomes \& Pires, Maria Coeli Simões (2008). Os consórcios públicos: aplicação na gestão de regiões metropolitanas, aglomerações urbanas e microrregiões, in Maria Coeli Simões Pires \& Maria Elisa Braz barbosa, Consórcios Públicos, Instrumento do Federalismo Cooperativo. Belo Horizonte: Fórum.

Martins, Ricardo Marcondes (2009-2010). As Normas Gerais de Direito Urbanístico. Revista Eletrônica sobre Reforma do Estado n. ${ }^{\circ}$ 20. Salvador/Bahia. Disponível em: www.direitodoestado.com. Acesso em: 9 abril de 2015.

Meirelles, Hely Lopes (2001). Direito Municipal Brasileiro, 12 ed. São Paulo: Malheiros.

Mello, Celso Antônio Bandeira de (2011). O conteúdo jurídico do princípio da igualdade. São Paulo: Malheiros.

Mencio, Mariana (2012). Considerações acerca da constitucionalidade dos dispositivos legais que priorizam o acesso aos incentivos financeiros da União para os Estados e Municípios integrantes de microrregiões na elaboração dos planos estaduais e municipais de resíduos sólidos. Boletim de Direito Administrativo XXVII (10). São Paulo: NDJ, p. 712-738.

Mencio, Mariana (2012). Considerações jurídicas sobre as Constituições Estaduais que introduzem o plebiscito e o referendo como Instrumento de Participação Popular no Processo Legislativo de criação das Regiões Metropolitana. Boletim de Direito Administrativo XXVIII (4). São Paulo: NDJ, p. 427-446.

Mencio, Mariana (2014). Regime Jurídico dos Planos Diretores Metropolitanos. Tese de doutorado defendida no dia 18/2/2014, perante banca examinadora na Pontifícia Universidade Católica.

Mendes, Gilmar Ferreira, Coelho, Inocêncio Mártires \& Gonet Branco, Paulo Gustavo. (2009). Curso de Direito Constitucional, 4 ed. São Paulo: Saraiva.

Motta Meirelles, Diana \& Ajara, César (2000). Rede urbana brasileira: bierarquia de cidades. Belo Horizonte: Fundação João Pinheiro. 
SAUle JúnIOR, NelSON (2007). Bases jurídicas para a instituição de uma Lei Federal sobre o sistema nacional de desenvolvimento urbano, in NeLSON SAULE JUNIOR (coord.), Direito Urbanístico, vias jurídicas das políticas urbanas. Porto Alegre: Sérgio Antonio Fabris.

SAmpaiO, CÁRITA da Silva (2013). Relatório de pesquisa do projeto: Governança Metropolitana no Brasil. Caracterização e quadros de análise comparativa da Governança Metropolitana no Brasil. Arranjos institucionais de gestão metropolitana. Companhia de Planejamento do Distrito Federal (CODEPLAN). Brasília: IPEA.

Serrano, Pedro Estevam Alves Pinto (2009). Região Metropolitana e seu regime constitucional. São Paulo: Verbatim.

Silva, José Afonso da (2012). Direito Urbanístico Brasileiro, 7 ed. São Paulo: Malheiros.

Spink, Peter Kevin, Teixeira Carvahlo, Marco Antônio \& Clemente, Roberta (2009). Governança. Governo ou gestão: O caminho das ações metropolitanas. Cadernos Metrópole 11 (22), jul.-dez. São Paulo.

Teixeira, Ana Carolina Wanderley (2009). Região Metropolitana, Instituição e Gestão Contemporânea. Dimensão Participativa, 2 ed. Belo Horizonte: Fórum. 